\title{
Derivative Spectrophotometric and Isocratic High Performance Liquid Chromatographic Methods for Simultaneous Determination of Repaglinide and Metformin Hydrochloride in Pharmaceutical Preparations
}

\author{
Serap Sağlık Aslan*, Berna Yılmaz \\ Department of Analytical Chemistry, Faculty of Pharmacy, Istanbul University, Istanbul, Turkey \\ Email: *ssaglik@istanbul.edu.tr, *serapsaglik@yahoo.com
}

How to cite this paper: Aslan, S.S. and Yllmaz, B. (2017) Derivative Spectrophotometric and Isocratic High Performance Liquid Chromatographic Methods for Simultaneous Determination of Repaglinide and Metformin Hydrochloride in Pharmaceutical Preparations. American Journal of Analytical Chemistry, 8, 541-552.

https://doi.org/10.4236/ajac.2017.89039

Received: July 21, 2017

Accepted: September 3, 2017

Published: September 6, 2017

Copyright $\odot 2017$ by authors and Scientific Research Publishing Inc. This work is licensed under the Creative Commons Attribution International License (CC BY 4.0).

http://creativecommons.org/licenses/by/4.0/

\begin{abstract}
In this study, a derivative spectrophotometric method and one HPLC method were developed and validated for analysis of anti-diabetic drugs, repaglinide (RPG) and metformine hydrochloride (MTF) in tablets. The spectrophotometric methods were based on zero-crossing first-derivative and fourth-derivative spectrophotometric method for simultaneous analysis of RPG $(308 \mathrm{~nm})$ and MTF $(267 \mathrm{~nm})$, respectively. Linear relationship between the absorbance at $\lambda_{\max }$ and the drug concentration was found to be in the ranges of $5.0-50.0$ $\mu \mathrm{g} \cdot \mathrm{mL}^{-1}$ for both RPG and MTF. The quantification limits for RPG and MTF were found to be 0.568 and $1.156 \mu \mathrm{g} \cdot \mathrm{mL}^{-1}$, respectively. The detection limits were 0.170 and $0.347 \mu \mathrm{g} \cdot \mathrm{mL}^{-1}$ for RPG and MTF, respectively. The second method is a rapid stability-indicating isocratic HPLC method developed for the determination of RPG and MTF. A linear response was observed within the concentration range of $5.0-50.0 \mu \mathrm{g} \cdot \mathrm{mL}^{-1}$ for both RPG and MTF. The quantification limits for RPG and MTF were found to be 1.821 and 1.653 $\mu \mathrm{g} \cdot \mathrm{mL}^{-1}$, respectively. The detection limits were 0.601 and $0.545 \mu \mathrm{g} \cdot \mathrm{mL}^{-1}$ for RPG and MTF, respectively. The proposed methods were successfully applied to the tablet analysis with good accuracy and precision.
\end{abstract}

\section{Keywords}

Repaglinide, Metformin, Derivative Spectrophotometry, HPLC, Drug Analysis

\section{Introduction}

Oral hypoglycaemia agents consist of two major classes such as biguanides and 
sulfonylureas. Metformin and phenformin are the most commonly used drugs in biguanide class that have been established in the therapy of non-insulin-dependent diabetes mellitus for decades. However, after the introduction of sulfonylureas, biguanides were nearly eliminated from the market, largely because of the risk of severe lactic acidosis [1]. But metformin hydrochloride (1,1-dimethylbiguanide hydrochloride) (Figure 1(a)) doesn't cause hypoglycaemica or lactic acidosis like other hypoglycaemic agents. So, it is the most commonly used biguanide nowadays. It is an oral anti-diabetic drug, in particular, used for type II diabetes mellitus patients accompanying obesity and insulin resistance [2].

Glinides, the new class of insulin secretagogues, are named as such because of organic structural similarities to meglitinides. Repaglinide (Figure 1(b)), a carbamoylmethyl benzoic acide derivative, stimulates insulin release by closing ATP-dependent potassium channels in the membrane of the beta cells as sulfonylureas. It has been seen that repaglinide is especially useful in the first stage of type II diabetes when used as monotherapy or combination with metformin. It is absorbed rapidly and has a short term appropriate effect on prandial glucose control [3]. A combination of $500 \mathrm{mg}$ of metformin hydrochloride and $1 \mathrm{mg}$ of repaglinide is available commercially and indicated for the treatment of type 2 diabetes mellitus.

Several analytical methods have been reported for the determination of metformin such as liquid chromatography-tandem mass spectrometry [4], capillary electrophoresis [5], gas chromatography [6] and HPLC [7]. Also, electrochemical [8] and HPLC [9] methods are available for the determination of repaglinide. Even though simultaneous analysis of metformin with sulfonylureas such as glipizide and gliclazide, and also with RPG are carried out by using liquid chromatography [10] [11] [12], only one second derivative spectrophotometric method was encountered for simultaneous analysis of RPG and MTF in literature survey [13]. Therefore, a sensitive derivative spectrophotometric method was<smiles>CN(C)C(=N)NC(=N)N</smiles>

(a)<smiles>CCOc1cc(CC(=O)NCc2ccccc2N2CCCCC2)ccc1C(=O)O</smiles>

(b)

Figure 1. Chemical structures of (b) repaglinide and (a) metformin hydrochloride. 
developed and validated for simultaneous determination of RPG and metformin hydrochloride MTF in original fixed dose combination tablet preparations using a zero-crossing first-derivative for RPG and fourth-derivative for MTF accurately. The derivative UV-spectrophotometric method is very simple and requires no reagent, $\mathrm{pH}$-adjustment and extraction as compared to chromatographic technique, and can be used for routine analysis of RPG and MTF, simultaneously in fixed dose combination tablets in quality control laboratories.

In the second method, a simple, accurate, reproducible and rapid HPLC method with good resolution was developed and validated for determination of RPG and MTF in original tablets unaffected by interferences from the excipients without using an internal standard. The method proved is selective and useful for the investigation of the stability of RPG and MTF.

\section{Experimental}

\subsection{Reagents and Solutions}

RPG and MTF were kindly supplied by Zentiva Ilac (Istanbul, Turkey) and Deva Ilac (Istanbul, Turkey), respectively. Their combined pharmaceutical preparation Prandimet film tablet ${ }^{\circledR}$, containing $1 \mathrm{mg}$ of RPG and $500 \mathrm{mg}$ MTF per tablets was obtained from local pharmacy. All chemicals and reagents were of analytical-reagent grade.

For derivative spectrophotometric method, portions (10 mg each) of standard RPG and MTF were weighed and transferred to 2 separate $10 \mathrm{~mL}$ volumetric flasks and dissolved in methanol and further diluted with the same solvent to obtain standard solutions of RPG and MTF having final concentrations of 200 $\mu \mathrm{g} \cdot \mathrm{mL}^{-1}$ each of them.

For HPLC method, stock solutions of RPG and MTF were prepared in methanol to give a concentration of $1 \mathrm{mg} \cdot \mathrm{mL}^{-1}$ of RPG and MTF and then diluted further with the mobile phase (acetonitrile- $o$-phosphoric acid (40:60), $\mathrm{v} / \mathrm{v})$ to obtain standard solutions of $200 \mu \mathrm{g} \cdot \mathrm{mL}^{-1}$ each of them.

\subsection{Apparatus}

Spectrophotometric measurements were carried out using a Shimadzu UV-160 A spectrophotometer with 1-cm glass cells.

The HPLC analyses were performed on a Shimadzu LC-20A (Kyoto, Japan) which consisted of an LC-20AT solvent delivery system equipped with a Rheodyne injection valve, DGU-20A5 vacuum degasser, CTO-10ASVP column oven and SPDM20A photodiode array detector (PDA) at $225 \mathrm{~nm}$. The data was collected and analyzed via the automation system software. Separations were performed at room temperature on a Luna C18 column $(4.6 \mathrm{~mm}$ i.d. $\times 250 \mathrm{~mm}$, $5 \mu \mathrm{m}$ particle; Phenomenex, TX, USA), with a guard column $(4 \mathrm{~mm} \times 3 \mathrm{~mm}$ i.d.; Phenomenex) packed with the same material. The mobile phase consists of acetonitrile- $o$-phosphoric acid pH adjusted to 3 with $1 \mathrm{~N} \mathrm{NaOH}(40: 60), \mathrm{v} / \mathrm{v}$ at a flow rate of $1.0 \mathrm{~mL} \cdot \mathrm{min}^{-1}$. The mobile phase was degassed by an ultrasonic bath 
and filtered by a Millipore vacuum filter system equipped with a $0.45 \mathrm{~mm} \mathrm{HV}$ filter.

\subsection{General Procedure}

\subsubsection{Derivative Spectrophotometric Method}

Two diluted standards were prepared from the stock solutions of RPG and MTF, series $\mathrm{A}$ and $\mathrm{B}$, respectively, as follows: Different aliquots of drug solution $(0.125-1.25 \mathrm{~mL})$ were transferred to $5 \mathrm{~mL}$ volumetric flask to provide final concentration range $5.0-50.0 \mu \mathrm{g} \cdot \mathrm{mL}^{-1}$ and the volume was diluted to volume with methanol.

The absorbance of the standard solutions of RPG and MTF were measured at wavelengths of $308 \mathrm{~nm}$ and $267 \mathrm{~nm}$ for repaglinide and metformin, respectively.

\subsubsection{HPLC Method}

Two diluted standards were prepared from the stock solutions of RPG (series A) and MTF (series B), as follows:

Series A: Different aliquots of RPG solution $(0.125-1.25 \mathrm{~mL})$ were transferred to $5 \mathrm{~mL}$ volumetric flask to provide final concentration range 5.0 - $50.0 \mu \mathrm{g} \cdot \mathrm{mL}^{-1}$ and the volume was diluted to volume with mobile phase (acetonitrile- $o$ phosphoric acid (40:60), v/v).

Series B: Different aliquots of MTF solution $(0.125-1.25 \mathrm{~mL})$ were transferred to $5 \mathrm{~mL}$ volumetric flask to provide final concentration range $5.0-50.0 \mu \mathrm{g} \cdot \mathrm{mL}^{-1}$ and the volume was diluted to volume with mobile phase (acetonitrile- $o$ phosphoric acid (40:60), v/v).

The absorbance of the standard solutions of RPG and MTF were measured at wavelength of $225 \mathrm{~nm}$.

\subsubsection{Assay Procedure for Tablets}

For derivative spectrophotometric method, ten tablets were weighed and finely powdered. Powder equivalent to $1.0 \mathrm{mg}$ RPG and $500 \mathrm{mg}$ MTF was accurately weighed and transferred to a $50 \mathrm{~mL}$ volumetric flask. $25 \mathrm{~mL}$ methanol was transferred to the volumetric flask and then and then extraction was performed mechanically for $20 \mathrm{~min}$ and sonicated for 20 more minutes. The volume was brought to $50 \mathrm{~mL}$ with same solvent and the content was centrifuged for $10 \mathrm{~min}$. The stock solution containing $20 \mu \mathrm{g} \cdot \mathrm{mL}^{-1} \mathrm{RPG}$ and $10 \mathrm{mg} \cdot \mathrm{mL}^{-1}$ MTF was used for the determination of RPG. From this solution, $1.0 \mathrm{~mL}$ was transferred to a $500 \mathrm{~mL}$ volumetric flask. The volume was diluted with methanol to the mark to give a solution containing $0.04 \mu \mathrm{g} \cdot \mathrm{mL}^{-1} \mathrm{RPG}$ and $20 \mu \mathrm{g} \cdot \mathrm{mL}^{-1}$ MTF (Solution 1), which was used for the determination of MTF. RPG and MTF are present in very different quantities in the formulation which requires their measurement in different dilution levels to avoid any need for addition of RPG as standart to the sample solution; firstly RPG is measured at lower dilution then MTF at higher dilution.

For HPLC method, powder equivalent to $1.0 \mathrm{mg}$ RPG and $500 \mathrm{mg}$ MTF was 
accurately weighed and transferred to a $50 \mathrm{~mL}$ volumetric flask. $25 \mathrm{~mL}$ methanol was transferred to the volumetric flask and then extraction was performed mechanically for $20 \mathrm{~min}$ and sonicated for 20 more minutes. A $1 \mathrm{~mL}$ aliquot of the supernatant was diluted to $50 \mathrm{~mL}$ with the mobile phase. $20 \mu \mathrm{L}$ of its aliquot was injected and chromatographed $(\mathrm{n}=5)$ for the determination of RPG. From the solution above, $1 \mathrm{~mL}$ was transferred to a $500 \mathrm{~mL}$ volumetric flask. The volume was diluted with mobil phase to the mark to give a solution containing $0.04 \mu \mathrm{g} \cdot \mathrm{mL}^{-1} \mathrm{RPG}$ and $20 \mu \mathrm{g} \cdot \mathrm{mL}^{-1}$ MTF. A $20 \mu \mathrm{l}$ of its aliquot was injected and chromatographed $(n=5)$ for the determination of MTF.

\section{Results and Discussion}

\subsection{Derivative Spectrophotometric Method}

RPG and MTF are oral hypoglycemic agents. A fixed dose combination of 500 $\mathrm{mg}$ of MTF and $1 \mathrm{mg}$ of RPG is available commercially and indicated for the treatment of type 2 diabetes mellitus. For the simultaneous analysis of these drugs, a zero crossing first-derivative and fourth-derivative spectrophotometric method was developed in fixed dose combination tablet preparations. The absorption spectra of the two compounds, RPG and MTF were shown in Figure 2(a) and in Figure 2(b), respectively. Since spectral overlap is quite clear in this figures, simultaneous determination of these components cannot be performed. For this reason, the simultaneous determination of these drugs was not possible by direct measurements of absorbance in zero-order spectra. Derivative

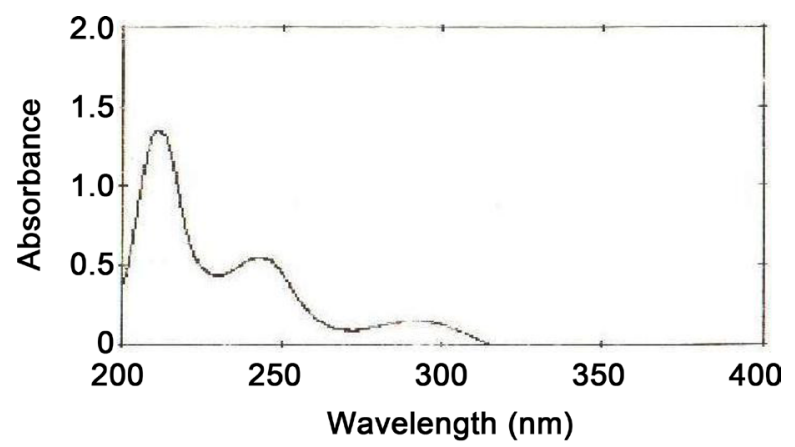

(a)

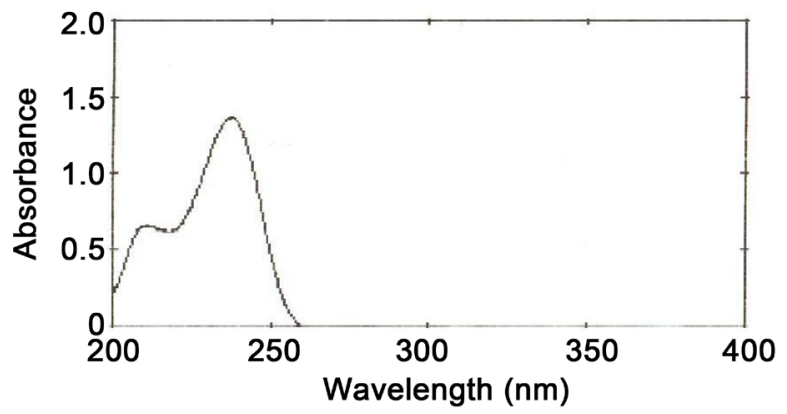

(b)

Figure 2. (a) Absorption spectra of repaglinide $\left(20 \mu \mathrm{g} \cdot \mathrm{mL}^{-1}\right)$ and (b) metformin hydrochloride $\left(20 \mu \mathrm{g} \cdot \mathrm{mL}^{-1}\right)$. 


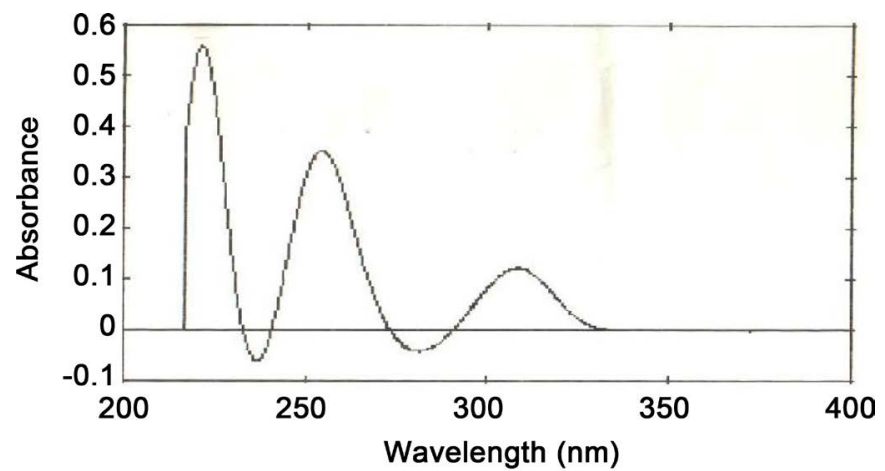

(a)

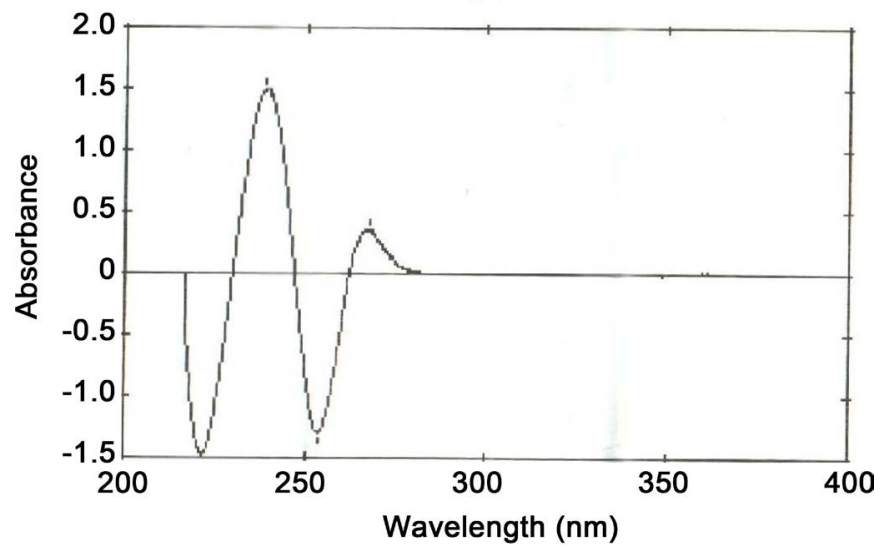

(b)

Figure 3. (a) First-derivative spectrum of repaglinide-metformin hydrochloride $\left(20 \mu \mathrm{g} \cdot \mathrm{mL}^{-1}\right)$ in methanol and (b) fourth-derivative spectrum of repaglinidemetformin hydrochloride $\left(20 \mu \mathrm{g} \cdot \mathrm{mL}^{-1}\right)$ in methanol.

spectrophotometry based on a mathematical transformation of the zero-order curve into the derivative spectra can overcome that problem [14] [15]. The RPG and MTF and also their mixture were prepared with methanol. Because the best results were obtained with it. After the first-fourth order derivative spectra were investigated, the first order derivative spectrum was selected for RPG when compared by the zero-crossing point (ZCP). As it can be seen on Figure 3, the wavelength $308 \mathrm{~nm}$ was selected for the determination of RPG (where the derivative response for MTF was zero). The fourth order derivative spectrum was selected for MTF when compared by ZCP. As it can be seen on Figure 3, the wavelength $267 \mathrm{~nm}$ was selected for the determination of MTF (where the derivative response for RPG was zero). Characteristic wavelengths (ZCP) for RPG and MTF were verified by working with various concentrations of each drug. For these reasons the second derivative method was not suitable for simultaneous determination of RPG and MTF in our experiments although it was used for determination of them in the literature [13].

\subsection{HPLC Method}

In order to separate RPG and MTF formed under given conditions, aqueous buffer-acetonitrile mixtures were used as the mobile phase. Satisfactory resolution 


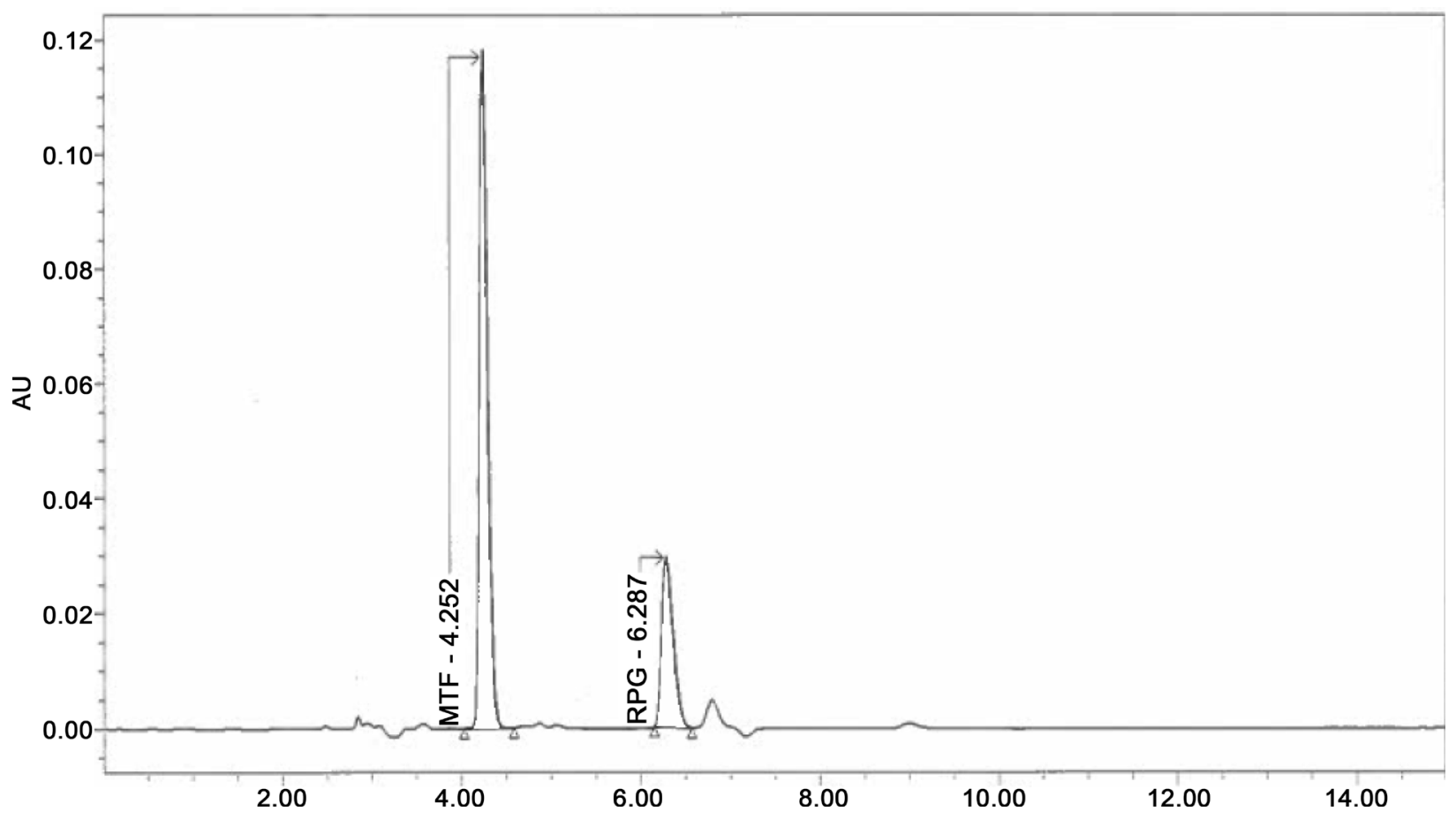

Figure 4. Chromatogram obtained with the mixture of repaglinide and metformin $\left(20 \mu \mathrm{g} \cdot \mathrm{mL}^{-1}\right)$.

was obtained using the mobile phase system of acetonitrile- $o$-phosphoric acid $(\mathrm{pH}: 3)(40: 60, \mathrm{v} / \mathrm{v})$ at a flow rate of $1.0 \mathrm{~mL} \cdot \mathrm{min}^{-1}$ using $\mathrm{C} 18$ column and UV detector was set at $225 \mathrm{~nm}$. In Figure 4, a typical chromatogram obtained under these conditions is presented. This chromatogram indicates that the developed method was successful for the separation of the drugs with sharp peaks and retention times were found to be $6.28 \mathrm{~min}$ and $4.25 \mathrm{~min}$ for RPG and MTF, respectively. Total run time was shorter and also sharp peak for RPG especially was occured than the literature [13].

\subsection{Method Validation}

\section{Linearity range}

In the derivative spectrophotometric method, the absorbances of the standard solutions were measured at wavelengths of $308 \mathrm{~nm}$ and $267 \mathrm{~nm}$ for RPG and MTF, respectively. The calibration curves were constructed by plotting the D1 values against RPG and D4 values against MTF. The concentration ranges were found to be $5.0-50.0 \mu \mathrm{g} \cdot \mathrm{mL}^{-1}$ for both RPG and MTF. In the HPLC method, the calibration curve was prepared by plotting the peak area of RPG and MTF against drug concentrations and they were linear within the range of $5.0-50.0$ $\mu \mathrm{g} \cdot \mathrm{mL}^{-1}$. Peak areas and concentrations were subjected to least square linear regression analysis for the calculation of the calibration equation and correlation coefficients (Table 1).

$L O D$ and $L O Q$

The limits of detection (LOD) and limits of quantitation (LOQ) were determined using the formula: $\mathrm{LOD}$ or $\mathrm{LOQ}=\mathrm{kSDa} / \mathrm{b}$, where $\mathrm{k}=3$ for $\mathrm{LOD}$ and 
10 for $\mathrm{LOQ}, \mathrm{SDa}$ is the standard deviation of the intercept, and $\mathrm{b}$ is the slope.

In the spectrophotometric methods, the LOD values were found to be 0.170 $\mu \mathrm{g} \cdot \mathrm{mL}^{-1}$ for RPG and $0.347 \mu \mathrm{g} \cdot \mathrm{mL}^{-1}$ for MTF. The LOQ values were found to be $0.568 \mu \mathrm{g} \cdot \mathrm{mL}^{-1}$ for RPG and $1.156 \mu \mathrm{g} \cdot \mathrm{mL}^{-1}$ for MTF $(\mathrm{n}=5)$. In the HPLC method, the LOD values were found to be $0.601 \mu \mathrm{g} \cdot \mathrm{mL}^{-1}$ for RPG and 0.545 $\mu \mathrm{g} \cdot \mathrm{mL}^{-1}$ for MTF. The LOQ values were found to be $1.821 \mu \mathrm{g} \cdot \mathrm{mL}^{-1}$ for RPG and $1.653 \mu \mathrm{g} \cdot \mathrm{mL}^{-1}$ for MTF $(\mathrm{n}=5)($ Table 1$)$.

\section{Precision}

The inter- and intra-day precision studies were carried out by analysis of drugs for the same day and seven consecutive days (each $\mathrm{n}=5$ ). The RSD values for intra-day precision were $0.61 \%-0.92 \%$ and interday precision was $1.18 \%$ $1.91 \%$ for all developed methods indicating good precision. The obtained results are summarized in Table 1.

\section{Recovery}

For recovery studies, the standard addition technique was applied. Certain amounts of pure sample solution was added to different concentrations of the standard drug mix solution and assayed. The percent recovery was was calculated from:

$$
\text { Recovery } \%=\left[\left(C_{t}-C_{u}\right) / C_{a}\right] \times 100
$$

where $C_{t}$ is the total concentration the analyte found; $C_{u}$ is the concentration of the analyte present in the formulation; and $C_{a}$ is the concentration of the pure analyte added to the formulation. The results of recovery analysis are given in Table 2. The recovery values $(99.73 \%$ - 101.42\%) indicate that the proposed methods have good accuracy.

\section{Stability}

The stability was tested at some storage conditions (room temperature in the dark for $48 \mathrm{~h}$; autosampler conditions for $24 \mathrm{~h}$ and $4^{\circ} \mathrm{C}$ for 1 week). As a result of stability studies the samples were stable when kept at room temperature in the dark for $48 \mathrm{~h}$, in autosampler conditions $24 \mathrm{~h}$ and refrigerated at $4^{\circ} \mathrm{C}$ for 1 week.

Table 1. Results of validation parameters for proposed methods.

\begin{tabular}{ccccc}
\hline \multirow{2}{*}{ Parameters } & \multicolumn{2}{c}{ Derivative spectrophotometric methods } & \multicolumn{2}{c}{ HPLC method } \\
\cline { 2 - 5 } & RPG & MTF & RPG & MTF \\
\hline Linearity range $^{\mathrm{a}}(\mu \mathrm{g} / \mathrm{mL})$ & $5.0-50.0$ & $5.0-50.0$ & $5.0-50.0$ & $5.0-50.0$ \\
Intra-day $^{\mathrm{b}}, \mathrm{RSD} \%$ & 0.92 & 0.85 & 0.76 & 0.61 \\
Inter-day $^{\mathrm{c}}, \mathrm{RSD} \%$ & 1.76 & 1.18 & 1.91 & 1.19 \\
Regression equation $^{\mathrm{d}}$ & $\mathrm{A}=0.0111 \mathrm{C}+0.0177$ & $\mathrm{~A}=0.0045 \mathrm{C}+0.0116$ & $\mathrm{~A}=12,687.68 \mathrm{C}+2930.32$ & $\mathrm{~A}=34,449.77 \mathrm{C}+12,527.40$ \\
Correlation coefficient, $\mathrm{r}$ & 0.9950 & 0.9999 & 0.9999 & 1.0000 \\
LOD $(\mu \mathrm{g} / \mathrm{mL})$ & 0.170 & 0.347 & 0.601 & 0.545 \\
LOQ $(\mu \mathrm{g} / \mathrm{mL})$ & 0.568 & 1.156 & 1.821 & 1.653 \\
\hline
\end{tabular}

${ }^{a}$ Average of six determinations. ${ }^{b} n=5$ Correspond to replicate analysis for each level. ${ }^{c}$ Results of three different days. ${ }^{\mathrm{d}} \mathrm{A}=\mathrm{mC}+\mathrm{b}$ (where $\mathrm{C}$ is the concentration of drug in $\mu \mathrm{g} / \mathrm{ml}, \mathrm{A}$ is the absorbance at $\lambda_{\max }$ for spectrophotometry and peak area for HPLC). 
Table 2. Results of recovery studies by standard addition method.

\begin{tabular}{|c|c|c|c|c|c|}
\hline & $\begin{array}{c}\text { Amount Taken } \\
(\mu \mathrm{g} / \mathrm{mL})\end{array}$ & $\begin{array}{l}\text { Amount Added } \\
(\mu \mathrm{g} / \mathrm{mL})\end{array}$ & $\begin{array}{l}\text { Total amount found } \\
(\mu \mathrm{g} / \mathrm{mL})\left(\text { Mean } \pm \mathrm{SD}^{\mathrm{c}}\right)\end{array}$ & Recovery (\%) & $\begin{array}{l}\text { RSD } \\
(\%)\end{array}$ \\
\hline \multicolumn{6}{|c|}{ Derivative spectrophotometric methods $s^{a}$} \\
\hline \multirow[t]{3}{*}{ RPG } & 5.0 & 5.0 & $9.996 \pm 0.092$ & 99.96 & 0.23 \\
\hline & & 10.0 & $15.213 \pm 0.022$ & 101.42 & 0.37 \\
\hline & & 20.0 & $25.105 \pm 0.067$ & 100.42 & 0.19 \\
\hline \multirow[t]{3}{*}{ MTF } & 5.0 & 5.0 & $10.010 \pm 0.046$ & 100.10 & 0.71 \\
\hline & & 10.0 & $14.998 \pm 0.032$ & 99.99 & 0.86 \\
\hline & & 20.0 & $25.012 \pm 0.011$ & 100.05 & 0.24 \\
\hline \multicolumn{6}{|l|}{ HPLC $^{a}$} \\
\hline \multirow[t]{3}{*}{ RPG } & 5.0 & 5.0 & $10.080 \pm 0.017$ & 100.80 & 0.32 \\
\hline & & 10.0 & $15.116 \pm 0.066$ & 100.77 & 0.65 \\
\hline & & 20.0 & $24.933 \pm 0.044$ & 99.73 & 0.22 \\
\hline \multirow[t]{3}{*}{ MTF } & 20.0 & 5.0 & $25.069 \pm 0.028$ & 100.28 & 0.56 \\
\hline & & 10.0 & $30.160 \pm 0.038$ & 100.53 & 0.38 \\
\hline & & 20.0 & $40.460 \pm 0.069$ & 101.15 & 0.22 \\
\hline
\end{tabular}

${ }^{a}$ Prandimet film tablet ${ }^{\circledR}$, containing $1.0 \mathrm{mg}$ of repaglinide and $500.0 \mathrm{mg}$ of metformin hydrochloride per tablets. ${ }^{\mathrm{b}}$ Five independent analyses. ${ }^{\mathrm{c}} \mathrm{SD}=\mathrm{Standard}$ deviation.

\section{Robustness}

The robustness of the HPLC method was determined by changing the flowrate, column oven temperature, sample temperature and mobile phase $\mathrm{pH}$. The flow-rate was changed from 0.9 to $1.1 \mathrm{~mL} \mathrm{~min}^{-1}$. The column oven temperature was changed from $23^{\circ} \mathrm{C}$ to $27^{\circ} \mathrm{C}$; the sample temperature was changed from $23^{\circ} \mathrm{C}$ to $27^{\circ} \mathrm{C}$; and the mobile phase $\mathrm{pH}$ was changed from 2.8 to 3.2. RSD and recovery (\%) results of study are given in Table 3.

System suitability parameters of study are given in Table 4. The good values for resolution, symmetry factor, plate count and tailing factor were obtained.

\section{Applications of the methods}

The proposed methods were applicated to determine of drugs in the pharmaceutical preparations. The results obtained are satisfactorily accurate and precise as indicated by the excellent \% recovery and RSD values (Table 5). Experiments showed that there was no interference from the additions and excipients, e.g. lactose, glucose, fructose, magnesium stearate and starch.

\section{Conclusions}

The aim of this study was to develop simple, fast, validated and very economic methods for the simultaneous analysis of RPG and MTF in original fixed dose combination pharmaceutical preparations.

For the simultaneous analysis of RPG and MTF in fixed dose combination tablets, the first-derivative and fourth-derivative spectrophotometric methods 
Table 3. Results from Robustness Experiment for HPLC Method.

\begin{tabular}{|c|c|c|c|c|c|}
\hline \multirow{2}{*}{ Condition } & \multirow{2}{*}{ Value } & \multicolumn{2}{|c|}{ Recovery (\%) } & \multicolumn{2}{|c|}{ RSD (\%) } \\
\hline & & RPG & MTF & RPG & MTF \\
\hline \multirow[t]{2}{*}{ Column temperature $\left({ }^{\circ} \mathrm{C}\right)$} & $23^{\circ} \mathrm{C}$ & 100.24 & 101.05 & 0.31 & 0.05 \\
\hline & $27^{\circ} \mathrm{C}$ & 100.43 & 101.12 & 0.21 & 0.02 \\
\hline \multirow[t]{2}{*}{ Sample temperature $\left({ }^{\circ} \mathrm{C}\right)$} & $23^{\circ} \mathrm{C}$ & 100.39 & 101.00 & 0.44 & 0.10 \\
\hline & $27^{\circ} \mathrm{C}$ & 100.12 & 101.22 & 0.42 & 0.08 \\
\hline \multirow[t]{2}{*}{ Mobile phase $\mathrm{pH}$} & 2.8 & 100.55 & 101.36 & 0.36 & 0.09 \\
\hline & 3.2 & 100.21 & 101.23 & 0.45 & 0.11 \\
\hline \multirow[t]{2}{*}{ Flow rate $(\mathrm{mL} / \mathrm{min})$} & 0.9 & 100.15 & 101.62 & 0.32 & 0.15 \\
\hline & 1.1 & 100.20 & 101.55 & 0.37 & 0.12 \\
\hline
\end{tabular}

Table 4. The results of system suitability parameters for HPLC method.

\begin{tabular}{|c|c|c|c|c|c|c|c|c|c|c|c|}
\hline \multirow{2}{*}{ Conditions } & \multirow{2}{*}{ Value } & \multicolumn{2}{|c|}{ Resolution } & \multicolumn{2}{|c|}{ Symmetry Factor } & \multicolumn{2}{|c|}{ EP Plate Count } & \multicolumn{2}{|c|}{ USP Plate Count } & \multicolumn{2}{|c|}{ USP Tailing Factor } \\
\hline & & RPG & MTF & RPG & MTF & RPG & MTF & RPG & MTF & RPG & MTF \\
\hline \multirow[t]{2}{*}{ Column Temperature $\left({ }^{\circ} \mathrm{C}\right)$} & $23^{\circ} \mathrm{C}$ & 11.6 & - & 1.24 & 1.26 & 13,554 & 12,582 & 13,067 & 12,158 & 1.24 & 1.26 \\
\hline & $27^{\circ} \mathrm{C}$ & 10.9 & - & 1.22 & 1.22 & 13,793 & 13,050 & 13,329 & 12,093 & 1.22 & 1.22 \\
\hline \multirow[t]{2}{*}{ Sample Temperature $\left({ }^{\circ} \mathrm{C}\right)$} & $23^{\circ} \mathrm{C}$ & 11.2 & - & 1.24 & 1.24 & 13,683 & 12,835 & 13,325 & 12,111 & 1.24 & 1.24 \\
\hline & $27^{\circ} \mathrm{C}$ & 11.0 & - & 1.22 & 1.20 & 13,467 & 12,795 & 13,167 & 12,005 & 1.22 & 1.2 \\
\hline \multirow[t]{2}{*}{ Mobile phase $\mathrm{pH}$} & 2.8 & 6.2 & - & 1.16 & 1.17 & 13,810 & 11,235 & 13,430 & 10,826 & 1.16 & 1.17 \\
\hline & 3.2 & 8.2 & - & 1.19 & 1.36 & 13,153 & 12,138 & 12,996 & 11,630 & 1.19 & 1.36 \\
\hline \multirow[t]{2}{*}{ Flow rate $(\mathrm{mL} / \mathrm{min})$} & 0.9 & 9.0 & - & 1.23 & 1.24 & 13,737 & 12,871 & 13,369 & 12,603 & 1.23 & 1.24 \\
\hline & 1.1 & 11.9 & - & 1.25 & 1.21 & 13,698 & 12,478 & 13,446 & 12,005 & 1.25 & 1.21 \\
\hline
\end{tabular}

Table 5. Analysis of RPG and MTF simultaneously using derivative spectrophotometric and HPLC methods in tablets containing $1.0 \mathrm{mg}$ RPG and $500.0 \mathrm{mg}$ MTF, respectively $(\mathrm{n}=5)$.

\begin{tabular}{|c|c|c|}
\hline Derivative spectrophotometric methods ${ }^{a}$ & RPG & MTF \\
\hline $\operatorname{Mean}^{\mathrm{b}} \pm \mathrm{SD}$ & $1.025 \pm 0.0054$ & $501.76 \pm 0.0077$ \\
\hline Recovery (\%) & 102.50 & 100.35 \\
\hline RSD (\%) & 0.77 & 0.96 \\
\hline HPLC method ${ }^{\mathrm{a}}$ & RPG & MTF \\
\hline $\operatorname{Mean}^{\mathrm{b}} \pm \mathrm{SD}$ & $1.01 \pm 0.01$ & $501.25 \pm 0.28$ \\
\hline Recovery (\%) & 101.00 & 100.25 \\
\hline RSD (\%) & 1.40 & 0.06 \\
\hline
\end{tabular}

${ }^{a}$ Prandimet film tablet ${ }^{\circledR}$, containing $1.0 \mathrm{mg}$ of repaglinide and $500.0 \mathrm{mg}$ of metformin hydrochloride per tablets; ${ }^{\mathrm{b}}$ Five independent analyses.

were proposed. Derivative spectroscopy shows better resolution and enables the method to analyse each drug in presence of one another as well as in presence of other excipients without any pretreatment. The proposed first-derivative and fourth-derivative spectrophotometric methods are simple, practical, inexpensive 
and fast with respect to analysis time when compared to chromatographic technique and the proposed method can be used for routine analysis of RPG and MTF, simultaneously in original fixed dose combination tablets without any prior separation in quality control laboratories.

Also, the proposed HPLC method provides simple, accurate, reproducible and rapid quantitative analysis for the simultaneous determination of RPG and MTF in tablets without any interference from the excipients. It is a simple analytical procedure and short retention time allows the analysis of a large number of samples in a short period of time. The proposed HPLC method for the determination of RPG and MTF has advantages over other analytical methods due to selectivity and better sensitivity.

\section{Acknowledgements}

This work was supported by Scientific Research Projects Coordination Unit of Istanbul University, Project number: 12275.

\section{References}

[1] Mercker, S.K., Maier C., Neumann, G. and Wulf, H. (1997) Lactic Acidosis as a Serious Perioperative Complication of Antidiabetic Biguanide Medication with Metformin. Anesthesiology, 87, 1003-1005. https://doi.org/10.1097/00000542-199710000-00043

[2] Kim, Y.D., Park, K.G., Lee, Y.S., Park, Y.Y., Kim, D.K., Nedumaran, B., Jang, W.G., Cho, W.J., Ha, J., Lee, I.K., Lee, C.H. and Choi, H.S. (2008) Metformin Inhibits Hepatic Gluconeogenesis through AMP-Activated Protein Kinase-Dependent Regulation of the Orphan Nuclear Receptor SHP. Diabetes, 57, 306-314. https://doi.org/10.2337/db07-0381

[3] Owens, D.R. (1998) Repaglinide-Prandial Glucose Regulator: A New Class of Oral Antidiabetic Drugs. Diabetic Medicine, 15, S28-S36.

https://doi.org/10.1002/(SICI)1096-9136(1998120)15:4+<S28::AID-DIA748>3.3.CO $\underline{; 2-\mathrm{K}}$

[4] Liu, A. and Coleman, S.P. (2009) Determination of Metformin in Human Plasma using Hydrophilic Interaction Liquid Chromatography-Tandem Mass Spectrometry. Journal of Chromatography B, 877, 3695-3700. https://doi.org/10.1016/j.jchromb.2009.09.020

[5] Song, J.Z., Chen, H.F., Tian, S.J. and Sun, Z.P. (1998) Determination of Metformin in Plasma by Capillary Electrophoresis Using Field-Amplified Sample Stacking Technique. Journal of Chromatography B, 708, 277-283. https://doi.org/10.1016/S0378-4347(97)00635-X

[6] Sane, R.T., Banavalikar, V.J., Bhate, V.R. and Nayak, V.G. (1989) Gas-Chromatographic Determination of Metformin Hydrochloride from Pharmaceutical Preparations. Indian Drugs, 26, 647-648.

[7] Liu, Q.F., Li, Z.D., Shi, X.J., Jiao, Z. and Zhong, M.K. (2009) Simple and Sensitive Determination of Metformin in Human Plasma using an Ion-Pair LC Method. Chromatographia, 70, 1511-1514. https://doi.org/10.1365/s10337-009-1339-x

[8] El-Ries, M.A.N., Mohamed, G.G. and Attia, A.K. (2008) Electrochemical Determination of the Antidiabetic Drug Repaglinide. Yakugaku Zasshi, 128, 171-177. https://doi.org/10.1248/yakushi.128.171 
[9] Venkatesh, P., Harisudhan, T., Choudhury, H., Mullangi, R. and Srinivas, N.R. (2006) Simultaneous Estimation of Six Anti-Diabetic Drugs-Glibenclamide, Gliclazide, Glipizide, Pioglitazone, Repaglinide and Rosiglitazone: Development of a Novel HPLC Method for Use in the Analysis of Pharmaceutical Formulations and Its Application to Human Plasma Assay. Biomedical Chromatography, 20, 1043-1048. https://doi.org/10.1002/bmc.635

[10] Aburuz, S., Millership, J. and McElnay, J. (2005) The Development and Validation of Liquid Chromatography Method for the Simultaneous Determination of Metformin and Glipizide, Gliclazide, Glibenclamide or Glimperide in Plasma. Journal of Chromatography B, 817, 277-286. https://doi.org/10.1016/j.jchromb.2004.12.018

[11] Soni, L.K., Narsinghani, T. and Jain, M. (2012) Development and Validation of RP-HPLC Method for Simultaneous Estimation of Metformin Hydrochloride and Repaglinide in Tablet Dosage Form. Journal of Liquid Chromatography \& Related Technologies, 35, 385-392. https://doi.org/10.1080/10826076.2011.601492

[12] Joshi, S.S., Nahire, R.R., Shastri, N.R., Surendranath, K.V. and Satish, J. (2012) Validated Stability-Indicating RP-HPLC UV Method for Simultaneous Determination of Metformin and Repaglinide. Acta Chromatographica, 24, 419-432. https://doi.org/10.1556/AChrom.24.2012.3.6

[13] Fouad, M.M. and Rashed, N.S. (2014) Development and Validation of Chromatographic and Spectroscopic Methods for Estimation of Repaglinide and Metformin $\mathrm{HCl}$ in Combined Dosage Form. Journal of Global Trends in Pharmaceutical Sciences, 5, 1844-1848.

[14] Singh, D.K. and Verma, R. (2007) Comparison of Second DerivativeSpectrophotometric and Reversed-Phase HPLC Methods for the Determination of Prednisolone in Pharmaceutical Formulations. Analytical Sciences, 23, 1241-1243. https://doi.org/10.2116/analsci.23.1241

[15] Nakarani, N.V., Bhatt, K.K., Patel, R.D. and Bhatt, H.S. (2007) Estimation of Atorvastatin Calcium and Fenofibrate in Tablets by Derivative Spectrophotometry and Liquid Chromatography. Journal of AOAC International, 90, 700-705.

Submit or recommend next manuscript to SCIRP and we will provide best service for you:

Accepting pre-submission inquiries through Email, Facebook, LinkedIn, Twitter, etc. A wide selection of journals (inclusive of 9 subjects, more than 200 journals)

Providing 24-hour high-quality service

User-friendly online submission system

Fair and swift peer-review system

Efficient typesetting and proofreading procedure

Display of the result of downloads and visits, as well as the number of cited articles

Maximum dissemination of your research work

Submit your manuscript at: http://papersubmission.scirp.org/

Or contactajac@scirp.org 